\title{
Influence of Consumer Behavior and Marketing Mix on Product Purchasing Decisions
}

\author{
Faye Maya Dewi ${ }^{1}$, Lod Sulivyo ${ }^{2}$, Listiawati ${ }^{3}$ \\ 1,2 Sekolah Tinggi Ilmu Ekonomi PPI \\ ${ }^{3}$ Universitas Bina Bangsa \\ 1,2Griya Harsa II, Jl. Citra Raya Utama Barat No.29, Sukamulya, Kec. Cikupa, Kabupaten \\ Tangerang, Banten 15710 \\ ${ }^{3} \mathrm{JL}$ Raya Serang - Jakarta, KM. 03 No. 1B, Panancangan, Kec. Cipocok Jaya, Kota Serang, \\ Banten 42124 \\ e-mail: fayemayadewi@stieppi.ac.id ${ }^{1}$, sulivyo.lod@stieppi.ac.id ${ }^{2}$, listiawati@binabangsa.ac.id $^{3}$
}

Author Notification 15 December 2021 Final Revised 2 February 2022

Published 1 July 2022

\section{To cite this document :}

Dewi, F.M., Sulivyo, L., \& Listiawati (2022). Influence of Consumer Behavior and Marketing Mix on Product Purchasing Decisions. Aptisi Transactions on Management (ATM), 6(2), 151-157.

DOI :

https://doi.org/10.33050/atm.v6i2.1737

\begin{abstract}
The purpose of the study was: 1) to look at the direct influence between consumer behaviour on the marketing mix, 2) to look at the direct relationship between consumer behaviour on purchasing decisions, 3) to look at the influence of direct relationships between marketing mixes on purchasing decisions, 4) to look at the indirect influence of indirect relationships between consumer behaviour toward purchasing decisions mediated by the marketing mix. The sample used in the study was as many as 120 randomly selected respondents, and data processing using Smart PLS 2.0 software. The results of this study are, 1) consumer behaviour towards the marketing mix has a positive and significant influence with a relationship value of 55,899 > 1.96. 2) Consumer behaviour towards purchasing decisions has a positive and significant influence with a relationship value of 2,850 > 1.96. 3) Marketing mix on purchasing decisions has a positive and significant influence value with a relationship value of $13,764>1.96$. 4) The results of analysis of indirect influence pathways between consumer behaviour to purchasing decisions mediated by marketing mix is 13,554 > 1.96 with a significance level of $5 \%$ proving that marketing mix has a significant effect in mediating the relationship between consumer behaviour to purchasing decisions.
\end{abstract}

Keywords: Consumer behaviour, Marketing mix, Purchasing decisions

\section{Introduction}

Improvements and refinements of activities in the field of marketing must be done in a planned manner, or in other words the company must determine the right marketing strategy. Changes in the business environment, especially in terms of competitors' ability to produce the same product, are causing many companies to turn to consumers. A consumer-focused business should always think about what consumers need, what consumers want and what services they like so that consumers are not only satisfied but also become loyal and buy again.[1] The Central Statistics Agency (BPS) released Indonesia's economic growth figures in 2020 , with growth down $2.07 \%$ (c-to-c) from 2019. Gross domestic product (GDP) based on prevailing prices, GDP reached Rp. 15,434.2 trillion and GDP per capita reached Rp. 56.9 million or US\$3,911.7. In terms of production, transportation and warehousing activities decreased the most, which was $15.04 \%$. In terms of expenditure, most of the components are contracted. The exported goods and services group was the group with the largest decline of $7.70 \%$. [2] Meanwhile, imports of goods and services that were a factor in the reduction fell by 
$14.71 \% .4,444$ Indonesia's economy in the fourth quarter of 2020 compared to the fourth quarter of 2019 decreased growth by $2.19 \%$ (y-on-y). In terms of production, the transportation and warehousing business grew the most strongly by $13.42 \%$. In terms of spending, the export component of goods and services experienced the strongest growth decline of $7.21 \%$. Meanwhile, imports of goods and services fell $13.52 \%$. Indonesia's economy in the fourth quarter of 2020 compared to the previous quarter grew by $0.42 \%$ (q-to- q). In terms of production, the agricultural, forestry, and fisheries sectors experienced the largest decline with an increase of $20.15 \%$. In terms of spending, the strongest growth was contributed by the Government Consumption Expenditure Component (PKP) which increased by $27.15 \%$. The spatial structure of Indonesia's economy in 2020 mainly focuses on the provinces on the island of Java at a rate of $58.75 \%$, with economic growth declining by $2.51 \%$.[2]

The variety of consumer behaviour to meet daily needs can be influenced by various factors, both from consumers themselves and those from outside the consumer. Several factors can influence consumer behaviour, including cultural, social, personal and psychological factors. So these factors need to be taken into account. The decision of consumers to buy goods and services, there are several factors found in consumer characteristics, namely business stimuli including products, prices, locations and promotions and as other stimuli such as politics, economy, technology and culture.[3] Consumer response to these stimuli will lead to decisions about the product, brand, agency, and when and how much to buy.[4]

The requirements that the Company must meet to be successful in the competition strive to achieve the goal of creating and maintaining customers. To this end, each company must create and deliver products and services that consumers want at affordable prices. Therefore, every company cannot understand consumer behaviour in the target market, since the company's survival as an organization with the aim of satisfying consumer needs and expectations is highly dependent on consumer behaviour. Not only that, especially if you have established a marketing strategy, consumers should learn and test the product. The process of consumer acceptance of products is implemented in the form of purchasing decisions. [5]

Marketing strategies include elements of an integrated marketing mix that is a product, price, distribution channels/ location and promotion that develop along with company activities and changes in the marketing environment, as well as changes in consumer behaviour. Consumption behaviour referred to here of course consumption behaviour that will bring revenue to the company. A marketing strategy is a set of goals and objectives, policies and rules that guide a company's marketing efforts at all times, at every level and its credentials and responsibilities, in particular, the company's response, environment and ever-changing competitive conditions.[6] Most people think that marketing is about sales and advertising. Sales and advertising are just the pinnacles of marketing. Today, marketing should not be understood in the old sales sense, but in the modern sense of meeting customer needs. Marketing creates value for customers and builds lasting relationships with customers to capture customer value.[7] Marketing is a social process in which a business creates value for an individual or group, customer or consumer by satisfying needs and wants through supply and demand.[8]

Purchasing behaviour describes how consumers make purchasing decisions and how they use and manage their purchases of goods or services. This consumption behaviour is dynamic, changing and moving all the time, which implies that generalizations of consumption behaviour are generally limited to a given period. Consumer behaviour is defined as actions directly related to the acquisition, consumption and disposal of products and services, including the decision-making process before and after those actions. Buying behaviour is influenced by many factors, including product, price, location and promotion of purchase.[9]

\section{Research Method}

The research method used is the survey method. The data used includes primary data and secondary data. The sample used in the study was 120 respondents. The data analysis used in this study is a statistical and descriptive analysis of Structural Equation Modeling (SEM) with Smart PLS 2.0M3 software. The rationale for the use of SEM is its ability to estimate relationships between variables with many relationships and to describe the pattern of relationships between latent constructs and expressed variables.[10] 


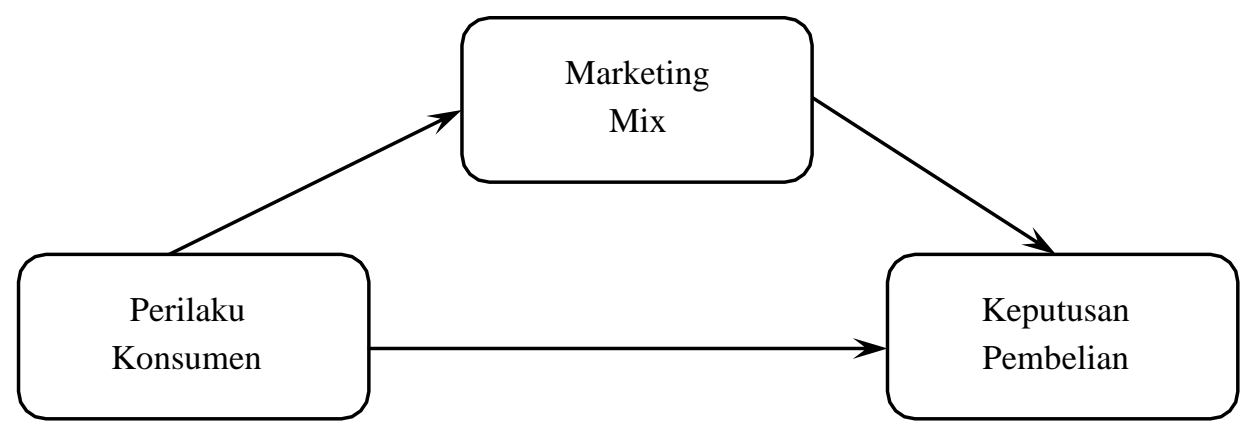

Figure 1. Framework of

2.1 Thought Results and Discussions Design research model

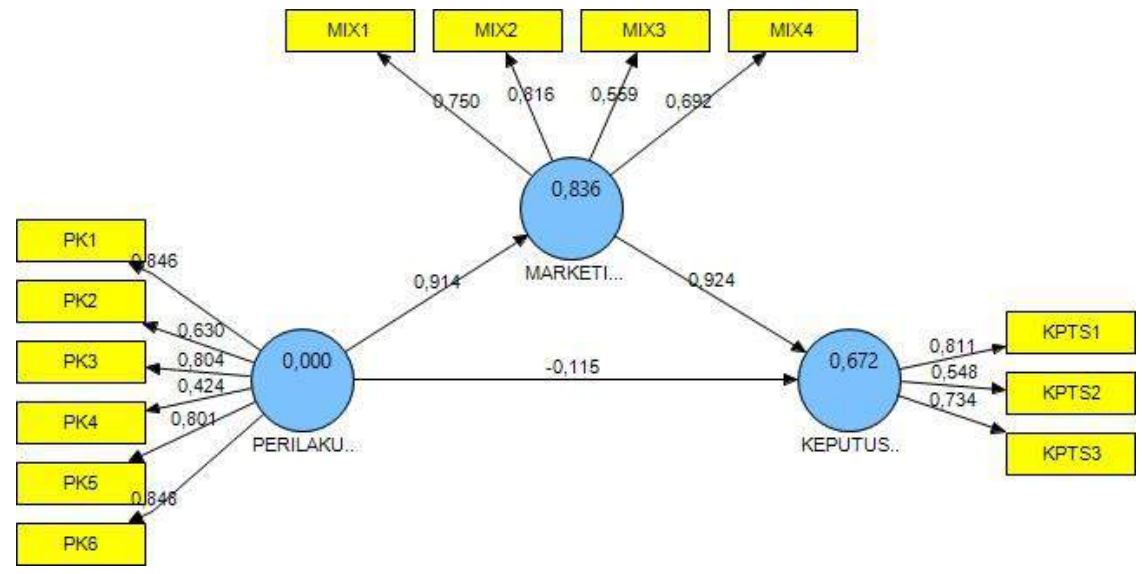

Figure 2. PLS Algorithm Results

From figure 2 above it is explained that the validity results of each variable indicator in this study use a validity standard of 0.5 . The PK4 indicator gets a value of 0.424 and is declared[11]

invalid because it has a validity value below the standard of 0.5 , and the decision taken related to the result is to remove the PK4 indicator and recalculate the validity results.[5]

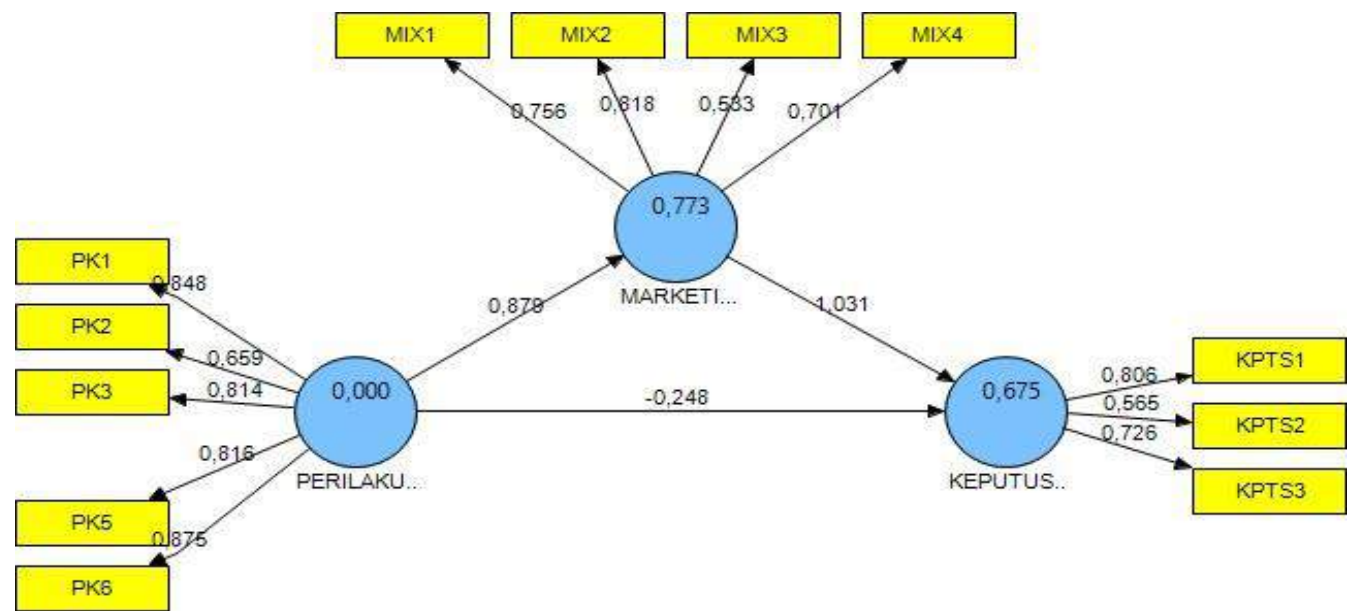

Figure 3. Algoritm PLS Results 
The results of the next calculation (figure 3 ) of the validity test of each indicator in this study have met the valid standard set at $>0.5 .[12]$

Convergent Validity Test

The reflective indicator validity test can use the relationship between the indicator score and the construct score.[5]

Table 1. Outer Loading Value

\begin{tabular}{|l|c|c|c|}
\hline & $\begin{array}{c}\text { Keputusan } \\
\text { Pembelian }\end{array}$ & $\begin{array}{c}\text { Marketing } \\
\text { Mix }\end{array}$ & $\begin{array}{c}\text { Perilaku } \\
\text { Konsumen }\end{array}$ \\
\hline KPTS1 & 0,805917 & & \\
\hline KPTS2 & 0,565237 & & \\
\hline KPTS3 & 0,725677 & & \\
\hline MIX1 & & 0,755607 & \\
\hline MIX2 & & 0,818413 & \\
\hline MIX3 & & 0,532624 & \\
\hline MIX4 & & 0,701116 & \\
\hline PK1 & & & 0,847661 \\
\hline PK2 & & & 0,659437 \\
\hline PK3 & & & 0,814469 \\
\hline PK5 & & & 0,816024 \\
\hline PK6 & & & 0,874733 \\
\hline
\end{tabular}

Discriminant Validity Test

For reflectance indexes, discriminant validity should be checked by comparing values in a cross-load table.[13] An indicator is declared valid if it has the highest load factor value for the target structure compared to the load factor value for other structures.[14]

Table 2. Cross Loading Results

\begin{tabular}{|l|c|c|c|}
\hline & $\begin{array}{c}\text { Keputusan } \\
\text { Pembelian }\end{array}$ & $\begin{array}{c}\text { Marketing } \\
\text { Mix }\end{array}$ & $\begin{array}{c}\text { Perilaku } \\
\text { Konsumen }\end{array}$ \\
\hline KPTS1 & 0,805917 & 0,688603 & 0,624740 \\
\hline KPTS2 & 0,565237 & 0,407578 & 0,153820 \\
\hline KPTS3 & 0,725677 & 0,593422 & 0,544513 \\
\hline MIX1 & 0,624822 & 0,755607 & 0,671965 \\
\hline MIX2 & 0,612983 & 0,818413 & 0,803137 \\
\hline MIX3 & 0,571217 & 0,532624 & 0,182435 \\
\hline MIX4 & 0,537385 & 0,701116 & 0,683892 \\
\hline PK1 & 0,579185 & 0,741376 & 0,847661 \\
\hline PK2 & 0,320602 & 0,481909 & 0,659437 \\
\hline PK3 & 0,593819 & 0,774620 & 0,814469 \\
\hline PK5 & 0,554210 & 0,760067 & 0,816024 \\
\hline PK6 & 0,549602 & 0,729218 & 0,874733 \\
\hline
\end{tabular}

Reliability Test

Table 3. Variable Reliability Test Results

\begin{tabular}{lcl}
\hline \multicolumn{1}{c}{ Construct } & Composite Reliability & Notes \\
\hline Keputusan Pembelian & 0,745065 & reliable \\
\hline Marketing Mix & 0,798936 & reliable \\
\hline Perilaku Konsumen & 0,901843 & reliable \\
\hline
\end{tabular}


Reliability test results showed the results of composite reliability of purchasing decisions of 0.745 , [15] marketing mix variables of 0.798 , and consumer behaviour of 0.901 , the results were very satisfactory because they were above the standard set at 0.7.[16]

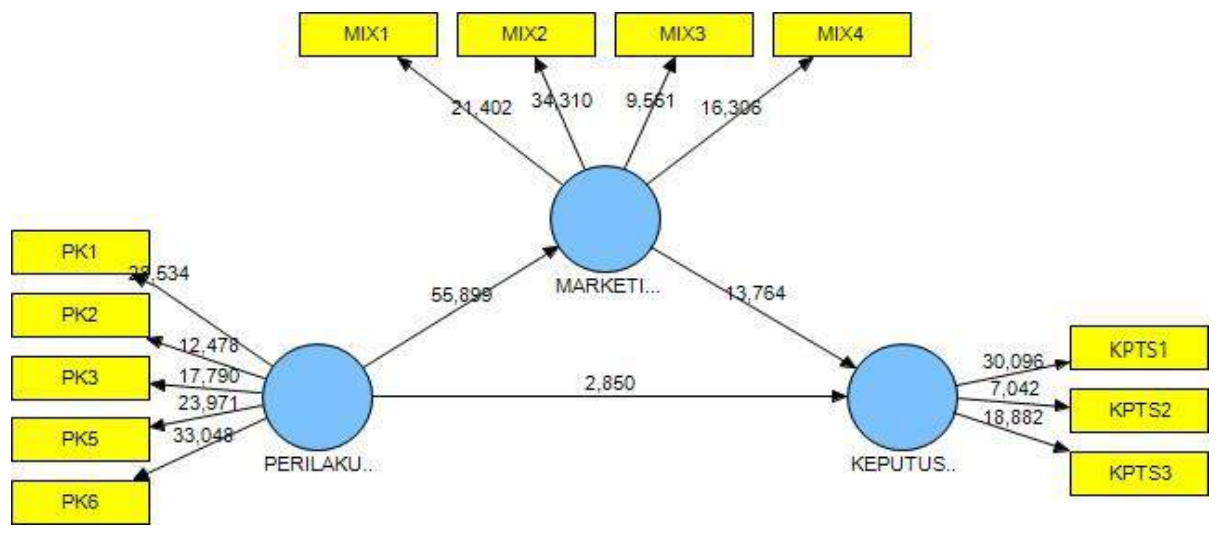

Figure 4. Bootstrapping Results

The results of the bootstrapping test to test the direct influence between the variables used in the study and to test the path hypothesis between each variable are used. From the results of the relationship between variables can be seen whether there is an influence or not between variables.[17] The results of consumer behaviour towards the marketing mix had a positive and significant influence with a relationship value of 55,899 >1.96.[18] The relationship between consumer behaviour and purchasing decisions had a positive and significant influence with a relationship value of $2,850>1.96$. The marketing mix related to the purchase decision has a positive and significant influence value with a relationship value of 13,764 > 1.96.[19]

Table 4. Conclusion of Research Results

\begin{tabular}{|c|c|c|c|c|c|c|c|}
\hline \multirow[b]{2}{*}{$\begin{array}{c}\text { Hypothesi } \\
\text { s }\end{array}$} & \multicolumn{2}{|c|}{$\begin{array}{c}\text { Variable } \\
\mathrm{s}\end{array}$} & \multirow{2}{*}{$\begin{array}{l}\text { Direc } \\
t \\
\text { Effect }\end{array}$} & \multirow{2}{*}{$\begin{array}{l}\text { Indirec } \\
t \\
\text { Effect }\end{array}$} & \multirow{2}{*}{$\begin{array}{l}\text { Total } \\
\text { Effec } \\
t\end{array}$} & \multirow{2}{*}{$\begin{array}{c}t- \\
\text { Value } \\
s \\
(>1.96 \\
1\end{array}$} & \multirow{2}{*}{ Notes } \\
\hline & Exogenous & Endogenous & & & & & \\
\hline 1 & $\begin{array}{l}\text { Perilaku } \\
\text { Konsumen }\end{array}$ & $\begin{array}{c}\text { Marketin } \\
\mathrm{g} \\
\mathrm{Mix}\end{array}$ & 0,879 & - & 0,879 & 55,899 & $\begin{array}{c}(+) \\
\text { Signifikan }\end{array}$ \\
\hline 2 & $\begin{array}{c}\text { Perilaku } \\
\text { Konsumen }\end{array}$ & $\begin{array}{l}\text { Keputusan } \\
\text { Pembelian }\end{array}$ & $-0,248$ & - & $-0,248$ & 2,850 & $\begin{array}{c}(+) \\
\text { Signifikan }\end{array}$ \\
\hline 3 & Marketing Mix & $\begin{array}{l}\text { Keputusan } \\
\text { Pembelian }\end{array}$ & 1,031 & - & 1,031 & 13,764 & $\begin{array}{c}(+) \\
\text { Signifikan }\end{array}$ \\
\hline 4. & $\begin{array}{c}\text { Perilaku } \\
\text { Konsumen } \\
\longrightarrow \\
\text { Marketing Mix }\end{array}$ & $\begin{array}{l}\text { Keputusa } \\
\mathrm{n} \\
\text { Pembelia } \\
\mathrm{n}\end{array}$ & 0,879 & $\begin{array}{c}1,03 \\
1\end{array}$ & 1,91 & 13,554 & $\begin{array}{c}(+) \\
\text { Signifikan }\end{array}$ \\
\hline
\end{tabular}


Indirect Effect

To see the results of indirect influence tests, the study used a Sobel test involving Consumer Behavior, Marketing Mix, and Purchasing Decisions.[20] Figure 5, shows the value of track analysis between consumer behaviour to the marketing mix of 0.879 with an error standard of 0.015 and marketing mix to purchasing decisions of 1,031 with a standard error of 0.074.[21] From the results of the Sobel test, the results of the analysis of indirect influence pathways between consumer behaviour to purchasing decisions mediated by marketing mixes were $13,554>1.96$ with a significance level of $5 \%$ proving that marketing mix has a significant effect in mediating the relationship between consumer behaviour to purchasing decisions.[22]

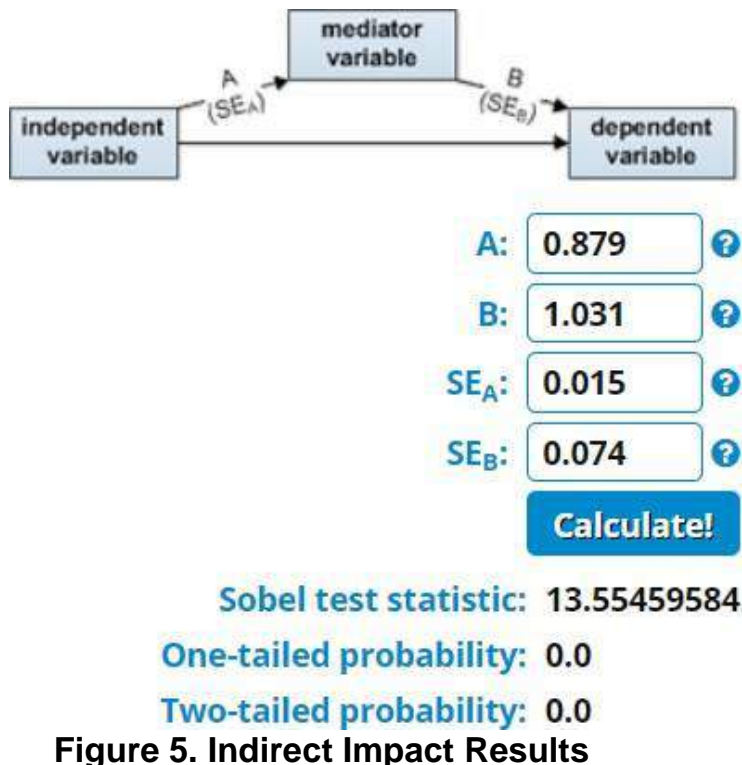

\section{Conclusion}

The first hypothesis, from the relationship between consumer behaviour to the marketing mix, has a positive and significant influence with a relationship value of 55,899 > 1.96. The second hypothesis is that the relationship between consumer behaviour toward purchasing decisions has a positive and significant effect with an associated value of 2,850 $>1.96$. The third hypothesis, the marketing mix relationship to purchasing decisions has a positive and significant influence value with a relationship value of $13,764>1.96$. The fourth hypothesis, the results of analysis of indirect influence pathways between consumer behaviour to purchasing decisions mediated by marketing mix is $13,554>1.96$ with a significance level of $5 \%$ proving that marketing mix has a significant effect in mediating the relationship between consumer behaviour to purchasing decisions.

\section{References}

[1] A. K. Jaelani, I. G. Ayu, K. Rachmi, and L. Karjoko, "The impact of corona virus on supply chain of halal tourism management in west Nusa Tenggara," Int. J. Supply Chain Manag., vol. 9, no. 5, pp. 823-831, 2020.

[2] A. S. Anwar, U. Rahardja, A. G. Prawiyogi, and N. P. L. Santoso, "iLearning Model Approach in Creating Blockchain Based Higher Education Trust," Int. J. Artif. Intell. Res., vol. 6, no. 1, 2022.

[3] G. R. Iyer, M. Blut, S. H. Xiao, and D. Grewal, "Impulse buying: a meta-analytic review," J. Acad. Mark. Sci., vol. 48, no. 3, pp. 384-404, 2020.

[4] Q. Aini, N. Lutfiani, N. P. L. Santoso, S. Sulistiawati, and E. Astriyani, "Blockchain For Education Purpose: Essential Topology," Aptisi Trans. Manag., vol. 5, no. 2, pp. 112120, 2021.

[5] Z. Fauziah, H. Latifah, U. Rahardja, N. Lutfiani, and A. Mardiansyah, "Designing Student Attendance Information Systems Web-Based," Aptisi Trans. Technopreneursh., vol. 3,

Influence of Consumer Behavior and Marketing Mix on Product Purchasing Decisions

(Faye Maya Dewi) 
no. 1 , pp. 23-31, 2021.

[6] S. Dziegielewski and D. C. Holliman, "The changing face of health care social work: Opportunities and challenges for professional practice," 2019.

[7] A. Payne, P. Frow, and A. Eggert, "The customer value proposition: evolution, development, and application in marketing," J. Acad. Mark. Sci., vol. 45, no. 4, pp. 467489, 2017.

[8] U. Rahardja, N. Lutfiani, S. Sudaryono, and R. Rochmawati, "The Strategy of Enhancing Employee Reward Using TOPSIS Method as a Decision Support System," IJCCS (Indonesian J. Comput. Cybern. Syst., vol. 14, no. 4, pp. 387-396, 2020.

[9] U. Rahardja, A. N. Hidayanto, N. Lutfiani, D. A. Febiani, and Q. Aini, "Immutability of Distributed Hash Model on Blockchain Node Storage," Sci. J. Informatics, vol. 8, no. 1, pp. 137-143, 2021.

[10] M. Knoll, R. J. Hall, and O. Weigelt, "A longitudinal study of the relationships between four differentially motivated forms of employee silence and burnout.," J. Occup. Health Psychol., vol. 24, no. 5, p. 572, 2019.

[11] Y. Yusmalina, T. Tegor, F. Haqiqi, R. E. Rosady, and N. Azura, "Comparative Analysis of Staretegi Traditional Market and Modern Markets of Consumer Valuation," Int. J. Multicult. Multireligious Underst., vol. 8, no. 11, pp. 18-25, 2021.

[12] L. Sulivyo, "CONSUMER VALUE, CONSUMER EXPERIENCE AND CONSUMER SATISFACTION," J. Cafe., vol. 2, no. 1, pp. 36-47, 2021.

[13] U. Rahardja, Q. Aini, E. P. Harahap, and R. Raihan, "GOOD, BAD AND DARK BITCOIN: A Systematic Literature Review," Aptisi Trans. Technopreneursh., vol. 3, no. 2, pp. 1-5, 2021.

[14] L. Sulivyo and A. Ekasari, "Impact of Eperiential Marketing and Perceived Quality on Brand Loyalty with Brand Trust as Mediation," Int. J. Multicult. Multireligious Underst., vol. 8, no. 8, pp. 397-409, 2021.

[15] A. K. Badri, J. Heikal, Y. A. Terah, and D. R. Nurjaman, "Decision-Making Techniques using LSTM on Antam Mining Shares before and during the COVID-19 Pandemic in Indonesia," APTISI Trans. Manag., vol. 6, no. 2, pp. 167-180, 2022.

[16] D. Karamehmedović, "'PUSH-PULL' ANALYSIS TOWARDS CREATING HOLISTIC MARKETING OF THE CULTURAL HERITAGE TOURISM DESTINATION: THE CASE STUDY OF DUBROVNIK," Ekon. misao i praksa, no. 1, pp. 29-51, 2018.

[17] N. Yulandha, J. I. Saputro, and N. K. Nissa, "Design Information System Accounting Sales Website-Based (Case Study: PT Arbunco Wira Pandega)," Aptisi Trans. Manag., vol. 4, no. 2, pp. 157-167, 2020.

[18] Q. Aini, E. P. Harahap, and F. Faradilla, "The Effects of Sales Reports Business Intelligence on Employee Performance," Aptisi Trans. Manag., vol. 4, no. 1, pp. 83-91, 2020.

[19] U. Rahardja, N. Lutfiani, and H. L. Juniar, "Scientific Publication Management Transformation In Disruption Era," Aptisi Trans. Manag., vol. 3, no. 2, pp. 109-118, 2019.

[20] T. Mariyanti, Y. Z. Basri, and J. Jazuli, "The Basic Factors Driving The Intention To Pay Zakat," APTISI Trans. Manag., vol. 6, no. 1, pp. 30-41, 2022.

[21] E. T. Susdarwono, "KONSEP PERTAHANAN SEBAGAI PUBLIC GOOD ATAU MONOPOLI ALAMIAH MENURUT SISTEM EKONOMI KERAKYATAN," J. Cafe., vol. 2, no. 2, pp. 98-110, 2021.

[22] T. Tegor, Y. Yusmalina, and F. Haqiqi, "PENERAPAN STANDAR AKUNTANSI DAN KUALITAS APARATUR TERHADAP LAPORAN KEUANGAN PEMERINTAH DAERAH (Studi Kasus pada Dinas Pekerjaan Umum dan Penataan Ruang Kabupaten Karimun)," J. Cafe., vol. 2, no. 1, pp. 13-24, 2021. 